\title{
Predicting a Pandemic: testing crowd wisdom and expert forecasting amidst the novel COVID-19 outbreak
}

- Emil O. W. Kirkegaard, Ulster Institute for Social Research, United Kingdom

- Wael Taji, PhD student, University of Chicago

- Arjen Gerritsen, Independent Researcher, the Netherlands

\begin{abstract}
Taking countermeasures to protect against future events requires predicting what the future will be like. In late 2019, a novel coronavirus known as NCov-2019 emerged in Wuhan, China, and has since spread to most countries in the world. Anticipatory responses by civilians facing the crisis have included self-isolation measures, extreme stockpiling of food or medical supplies, and other forms of preparation to meet the expected crisis. However, no consensus exists as to the accuracy of civilian expectations, nor toward the relative value of different informational sources used by citizens to build these expectations (e.g. mainstream news as opposed to an educational background in virology). In the present study, we used an online survey ( $n=333$ final sample) to collect individual characteristics and general knowledge regarding viruses and the novel coronavirus, in addition to their forecasts for the various outcomes expected to result from it in the near future. This will allow for the individual correlates of accurate forecasting to be known by 2021 , which could prove important for assigning relative weights to forecasts for other events in the future.
\end{abstract}

Keywords: Coronavirus, NCov-2019, COVID-19, SARS-CoV-2, science knowledge, forecasting, pandemic, wisdom of the crowd

\section{Introduction}

In late 2019, a novel coronavirus strain known as SARS-CoV-2 (severe acute respiratory syndrome coronavirus 2) emerged in Wuhan, China, and has since spread to most countries in the world (WHO, 2020). The rapidity of COVID's global spread has threatened supply chains and the provision of medical care from national healthcare systems (Heymann and Shindo, 2020), and many citizens in countries around the world have begun preparing for the possible long-term consequences of the virus by stockpiling medical equipment, house supplies, toilet paper, and non-perishable foods (Lufkin, 2020). In turn, self-described experts continue to accumulate predictions and analyses about the economic and public health impact of SARS-CoV-2 online, with estimates of total death toll ranging wildly from below $1 \%$ (timesave: add in any 
medium post or other informal 'superforecaster' prediction where the CFR is predicted as $<1 \%$ ) to an order of magnitude higher and beyond (timesave: add in any medium post or other informal 'superforecaster' prediction where the CFR is predicted as $>10 \%$ )

Whether experts or ordinary civilians, individuals who take countermeasures against expected future events must necessarily have a set of expectations concerning what those events will be like. For behaviors of resource stockpiling, wherein civilians rush to acquire a surplus of basic household items such as toilet paper, it is plausible that a vague expectation of near-future socioeconomic uncertainty, perhaps imparted by mainstream media reportage on the crisis, could be a relevant factor in the production of future expectations. But what about those who identify themselves as experts and forecasters? Basing our answer upon the established behavioral sciences literature (e.g. Kahneman and Tversky, 1973 [we could add more here]), it seems reasonable to surmise that in either case, a combination direct and indirect sources of contextually relevant information (i.e. any knowledge pertaining to SARS-CoV-2 or other public health crises) becomes constitutive of a predictive basis for assessing risk. By drawing upon sources of information such as the media, academic education, and autodidactically acquired knowledge among others, individuals produce expectations on both the probability and severity of adverse outcomes (i.e. a future disaster), the utility of countermeasures considered mitigative, and the total number of deaths or hospitalizations expected to incur as a consequence of the pandemic's ongoing spread. However, in the case of self-described expert forecasters, very few works (i.e. Mauksch, Gracht, \& Gordon, 2020) have analyzed either the sources of knowledge drawn upon, the distribution of accuracy in pre-event predictions, or both.

The present study aims to investigate how self-described experts build their expectations on the impact of future events like the ongoing spread of SARS-CoV-2, as well as the distribution of their predictions with respect to accuracy following the event. To do this, we recruited respondents to an online survey in which they self-described their political orientation, educational background, self-assessed familiarity with the ongoing coronavirus outbreak and cognitive orientation, as well as their expectations for various epidemiological outcomes associated with the outbreak by the end of the year. By referring back to these predictions by the time of 2021, we can assess the relationship between the participant characteristics recorded in this study (such as the frequency with which participants followed the mainstream news to acquire information on the coronavirus outbreak) and the accuracy of the predictions made. This provides a sorely-needed evidentiary basis to critically assess the degree to which governments and individuals can rely upon self-described 'superforecasters' or 'rationalists' to build personal expectations for the likely trajectory of the outbreak, and the degree to which education, political orientation, or other factors proves conducive to accurate outcomes in predictive responses.

\section{Methods and data}

We designed a survey intended to measure the following: 
1. An assortment of demographics questions:

- Age and sex

- Education and academic status (student, professorship etc.), as well as university major/field if applicable

- Country and city was provided by the survey software based on the IP data of the respondent.

2. Political beliefs:

- Political self-labels (centrist, ethnonationalist, communist, socialist, liberal, leftist etc.)

- Preferred income tax level

- Personal freedom index score (count of how many behaviors from a list they wish to legalize or keep legal)

3. Participation in Good Judgment Project, a forecasting tournament site run by Tetlock et al

4. A books read list, consistent of 11 books or book types where the respondent could say whether they read it or not. Books included were generally related to forecasting, rationality, cognitive psychology and related scientific fields.

5. Belief in genetic causation of human population differences (human biodiversity index)

6. Self-rated rationalism score, related to the rationalist movement/Less Wrong movement

7. Media questions:

- Accuracy of mainstream media (MSM)'s accuracy in reporting on CoV

- A scale of 0-100 on how closely they have been following the news related to $\mathrm{CoV}$

8. Personal safety: presented the subject with a list of 12 actions and asked to indicate which they have taken in response to the CV outbreak

9. A question asking the subject to rate their own score on the fox-hedgehog scale (5 levels)

10. Scientific knowledge test

- 15 items concerning CV related knowledge

- 15 items concerning knowledge of the scientific fields of medicine, epidemiology, virology, statistics, etc.

11. A question asking the subject to estimate their own performance on the science test (0-30 items right)

12. Forecasting questions: 18 questions asking the subject to estimate the probability of future events or numerical values

- 4 questions about the total death toll in: USA, Europe, United Kingdom, Poland

- 4 questions about when the CV infection rate will peak in: USA, Germany, Europe, United Kingdom

- 4 questions about the prevalence of CV infections by the end of $2020 \mathrm{in}$ : France, Italy, Spain, USA

- 4 questions about whether countries will declare a state of emergency in response to CV in: USA, Germany, United Kingdom, Sweden 
- 2 questions about own and immediate family's chances of becoming infected by $\mathrm{CV}$

13. A question asking the subjects how accurate their forecasts will be (0-100)

14. One question asking whether the subject has honestly answered the questions

- Used to filter out bad unserious responses

15. Email (if we may contact them)

16. Comments (open text field)

17. Attention check (multiply $12 \times 3$ )

Upon completion of the survey, the user was shown their own total score (sumscore) on the 30 science items. The median time to complete the survey was 21 minutes, with a rescaled median absolute deviation (MAD) of 9.39 minutes. ${ }^{1}$ These are robust alternatives to the mean, and standard deviation (SD) metrics, respectively.

\section{Science knowledge test design}

We designed a test composed of 30 questions to measure general knowledge of virology and biology as well as knowledge of the novel coronavirus and the coronavirus disease COVID-19. Due to the relatively short attention span of internet users and lack of financial incentives our objective was to design a test participants could complete in five to ten minutes. We use select-response test items such as multiple-choice and true-false matching because participants can respond to large numbers of questions in a limited amount of time and the answers can be scored automatically. Complex-performance assessments such as written essays were not used because they don't have these properties (fast responses, machine scoring). Two virology textbooks (Dimmock 2016, Louten 2016) as well as some wikipedia pages and scientific publications were used to formulate questions and possible answers. A third textbook was consulted but we concluded its questions were far too difficult to use. For questions about the new coronavirus we relied on information from the World Health Organization and European Centre for Disease Prevention and Control, a recent Lancet study (Chen et. al, 2019) various news websites and press agencies such as Reuters. A textbook (Miller, 2009) was used to review different methods of assessment and test items. We scored the test using the simple sum of correct answers, yielding a possible score range from 0 to 30 . This score was automatically shown to the subjects at the end of the survey.

\section{Subject recruitment}

To gather data, we posted the survey on Twitter leveraging the large follower base of the first author (EOWK, https://twitter.com/KirkegaardEmil, approximately 9,700 followers at time of posting ${ }^{2}$ ). These followers are generally men, ages 18 to 40 , who are interested in science, and who politically are right of center. To entice the users to take part, the first author repeatedly posted links to the survey, along with preliminary results from parts of

\footnotetext{
${ }^{1}$ The rescaling is done to put the MAD on the same scale as the SD. It is approximately 1.48 . See https://rdrr.io/cran/psych/man/describe.html.

2 Tweets: https://twitter.com/KirkegaardEmil/status/1237853755615236097,

https://twitter.com/KirkegaardEmil/status/1238540330800201728, https://twitter.com/KirkegaardEmil/status/1238316297009745921, https://twitter.com/KirkegaardEmil/status/1238680680705470464,
} 
the data. The intentional element of selection bias with respect to subject choice used in our study means that subjects may have been aware to some degree of certain aspects of the data (and thus that responses were not entirely independent), but due to both the preliminary nature of our current data collection methods and the urgency of collecting forecasts prior to the escalation of the pandemic, this was considered to be a necessary compromise.

\section{Data and materials availability}

The raw data and the survey materials are available in the study OSF repository: https://osf.io/9ecwv/. The raw data exclude a few variables that contain identifying information (IP and browser settings).

\section{Results}

\section{Sample characteristics}

A total of 369 complete responses were submitted. Of these, 355 (96.7\%) were marked as honest by the subjects. A few subjects provided invalid age data, and were removed, and the total usable sample size was 355 . The data were mostly collected from the 11 th to 15th March 2020 (92.4\% before 15th). We limited our dataset here to data collected up and including the 18th March, to avoid excessive time-variation in our data. This resulted in a final sample size of 333 .

The survey population was $90 . \%$ male. The mean/SD of age was $32.7 / 11.4$, with a range from 18 to 68 . Thus the survey was quite representative of the non-elderly adult population with an oversampling of younger adults. ${ }^{3}$ Figure $X$ shows the age distribution by sex.

\footnotetext{
${ }^{3}$ The mean age of persons aged 18-65 in a typical Western country is approximately 40.
} 


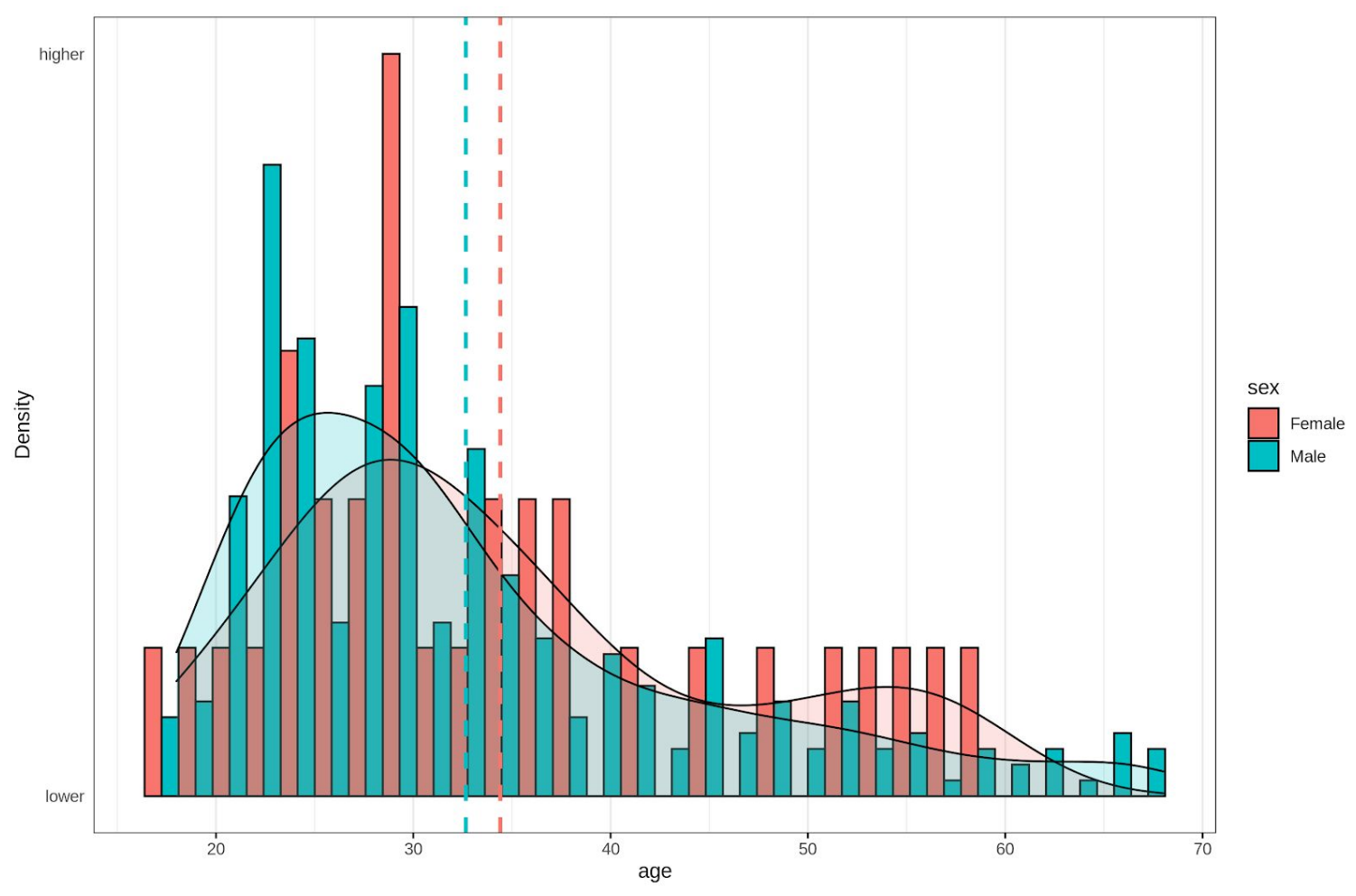

Figure X. Age distribution by sex.

People from many countries took part in the survey, but mainly persons from Western countries. Table X. shows the distribution by country.

\begin{tabular}{|l|l|l|}
\hline Country & Count & Percent \\
\hline $\begin{array}{l}\text { United } \\
\text { States }\end{array}$ & 157 & 47.15 \\
\hline $\begin{array}{l}\text { United } \\
\text { Kingdom }\end{array}$ & 46 & 13.81 \\
\hline Australia & 13 & 3.90 \\
\hline France & 12 & 3.60 \\
\hline Germany & 11 & 3.30 \\
\hline Norway & 9 & 2.70 \\
\hline Sweden & 9 & 2.70 \\
\hline Canada & 7 & 2.10 \\
\hline Ireland & 6 & 1.80 \\
\hline
\end{tabular}




\begin{tabular}{|l|l|l|}
\hline Netherlands & 6 & 1.80 \\
\hline
\end{tabular}

Table X. Distribution by country, 10 largest countries.

Educational attainment was very skewed towards the higher end, shown in table X.

\begin{tabular}{|l|l|l|}
\hline Education & Count & Percent \\
\hline Bachelor & 128 & 38.44 \\
\hline High school & 79 & 23.72 \\
\hline Master & 77 & 23.12 \\
\hline $\begin{array}{l}\text { Doctorate or } \\
\text { higher }\end{array}$ & 35 & 10.51 \\
\hline $\begin{array}{l}\text { Vocational } \\
\text { school }\end{array}$ & 10 & 3.00 \\
\hline None & 4 & 1.20 \\
\hline
\end{tabular}

Table X. Distribution of educational attainment.

With regards to researcher status, $81.7 \%$ indicated they were not researchers, $8.1 \%$ (27 persons) were published researchers not working in academia, $7.5 \%$ classified themselves as Other status, and the remaining were professors (9 persons).

The political labels in the study showed some relationships as expected. We computed the correlation matrix of latent (tetrachoric) correlations for these, shown in Figure $\mathrm{X}$. 


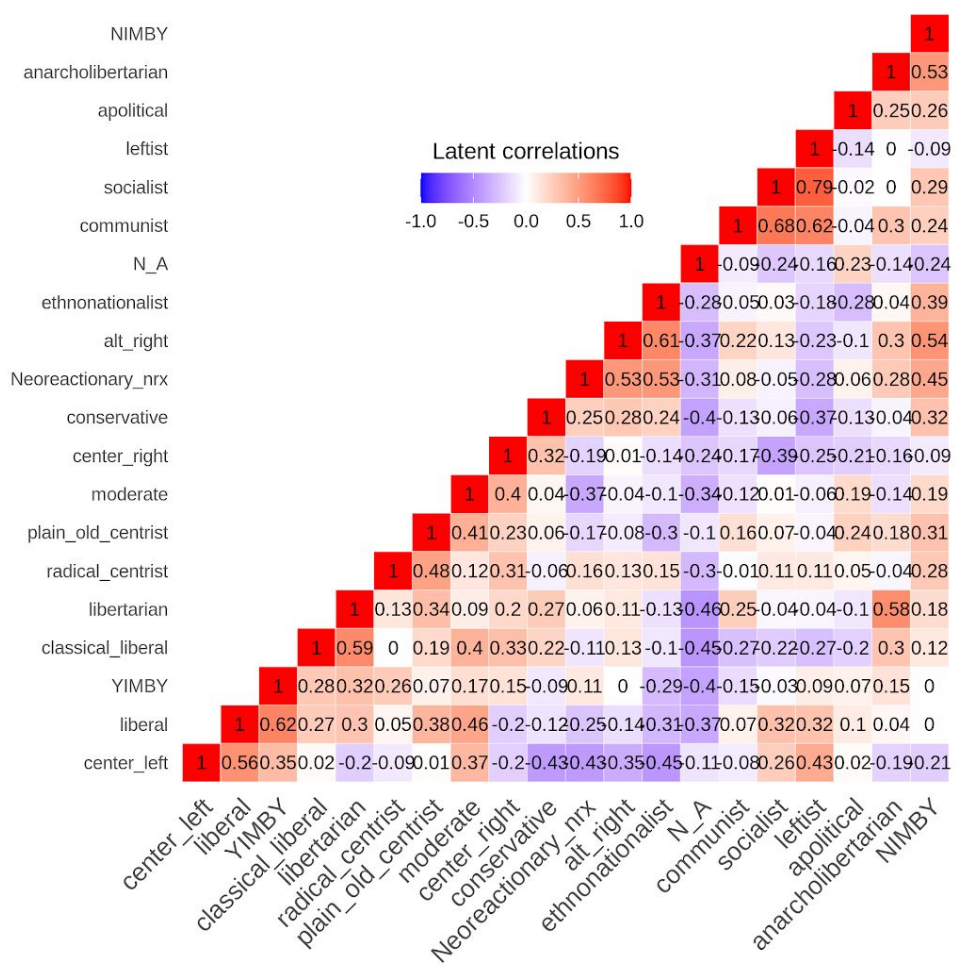

Figure X. Heatmap of political label correlations.

In order to avoid relying upon $\sim 20$ variables in our regression models later on in our study, we utilized factor analysis to interpret the political labels provided by survey participants. A three factor oblique solution seemed to produce the most sensible results. The first factor was an alt-right-like factor, with high loadings on NIMBY (Not In My BackYard; .67), alt-right (.77), neoreactionary (.72), and ethnonationalist (.66). The second factor was a libertarian-like factor with high loadings on classical liberal (.71), libertarian (.65), and liberal (.60). The third factor was a left-liberal-like factor with high loadings on leftist (.86), socialist (.85), and communist (.71). Scores from these were saved for further analysis.

With regards to experience in the Good Judgment Project (https://www.gjopen.com/), $87.1 \%$ indicated they had no experience, $11.3 \%$ (38 persons) had only a little bit, $1.2 \%$ had quite a bit and 1 person had a lot $(0.3 \%)$. On the fox-hedgehog thinking style question $^{4}$, the sample was tilted towards foxes. Converting the 5-level scale to numerical values gives a mean/SD of 2.37/1.09. On self-rated rationalist identification, the mean was $58.2 \%$ with a standard deviation of 25.7 . On the question of population differences

\footnotetext{
4 "In a famous essay, Isaiah Berlin classified thinkers as hedgehogs and foxes: The hedgehog knows one big thing and tries to explain as much as possible using that theory or framework. The fox knows many small things and is content to improvise explanations on a case-by-case basis. When it comes to making predictions, would you describe yourself as more of a hedgehog or more of a fox?"
} 
(human biodiversity for populations) $^{5}$, the mean response was $76.0 \%$, with an SD of $29.7 \%$

\section{Science knowledge results}

The science test questions are available in the supplementary materials. We scored the items using the answer key to derive the correct/incorrect status for each response, and then summed the items for each person to produce their sumscore, a simple metric to indicator their ability level. The alpha reliability for this was .70. We also used item response theory (IRT) to score the items, assuming a simple g-only model. We used irt.fa() in the psych package for $R$ for this. Table $X$ shows the item statistics.

\begin{tabular}{|l|l|l|l|}
\hline Item & Pass rate & Loading & Discrimination \\
\hline item_1 & 0.30 & 0.33 & 0.35 \\
\hline item_2 & 0.85 & 0.33 & 0.35 \\
\hline item_3 & 0.71 & 0.22 & 0.22 \\
\hline item_4 & 0.86 & 0.42 & 0.47 \\
\hline item_5 & 0.43 & 0.10 & 0.10 \\
\hline item_6 & 0.14 & 0.17 & 0.17 \\
\hline item_7 & 0.62 & 0.14 & 0.14 \\
\hline item_8 & 0.25 & 0.25 & 0.26 \\
\hline item_9 & 0.35 & 0.38 & 0.42 \\
\hline item_10 & 0.13 & 0.55 & 0.65 \\
\hline item_11 & 0.92 & 0.31 & 0.32 \\
\hline item_12 & 0.24 & 0.37 & 0.40 \\
\hline item_13 & 0.54 & 0.32 & 0.34 \\
\hline item_14 & 0.86 & 0.42 & 0.47 \\
\hline item_15 & 0.59 & 0.21 & 0.21 \\
\hline item_16 & 0.78 & 0.62 & 0.79 \\
\hline
\end{tabular}

5 “'Genetic variation contributes substantially to psychological and socioeconomic variation between human populations (clusters, races etc.), being ultimately responsible for at least $50 \%$ of observed differences." How likely do you think this statement is true?' 


\begin{tabular}{|l|l|l|l|}
\hline item_17 & 0.77 & 0.42 & 0.47 \\
\hline item_18 & 0.80 & 0.26 & 0.27 \\
\hline item_19 & 0.63 & 0.53 & 0.62 \\
\hline item_20 & 0.41 & 0.28 & 0.30 \\
\hline item_21 & 0.95 & 0.57 & 0.69 \\
\hline item_22 & 0.69 & 0.52 & 0.60 \\
\hline item_23 & 0.34 & 0.52 & 0.61 \\
\hline item_24 & 0.26 & 0.31 & 0.32 \\
\hline item_25 & 0.74 & 0.55 & 0.65 \\
\hline item_26 & 0.70 & 0.44 & 0.50 \\
\hline item_27 & 0.28 & 0.34 & 0.36 \\
\hline item_28 & 0.41 & 0.56 & 0.67 \\
\hline item_29 & 0.62 & 0.45 & 0.51 \\
\hline item_30 & 0.71 & 0.22 & 0.22 \\
\hline
\end{tabular}

Table X. Item statistics. Item loading is based on item response theory analysis, and rescaled to the usual loading scale ( -1 to 1$)$ from $z$ scale.

Item pass rate ranged from .127 to .946 , with a mean of .562 and SD of .246 . Thus, we had reasonably broad range coverage, and no clear floor or ceiling problems. Item loadings ranged from .10 to .62 with a mean of .37 and SD of .14 .5 items had quite low loadings $(5,6,7)$, which we arbitrarily define as below .20 , and should be discarded or changed in a revision. The IRT-derived scores correlated .93 with the sumscores, and were used for further analysis. The reliability of this score was estimated to be .74 in the present sample. $^{6}$

The distribution of sumscores showed that there were no problems with ceiling or floor effects, as no one attained perfect scores, maximum observed score was 26 (of 30). The distribution of sumscores was nearly perfectly normal: skew was -0.08 and kurtosis was -0.28 . Figures $X a-b$, show the IRT score distribution by sex and age.

\footnotetext{
${ }^{6}$ This was done by refitting the data using the mirt package and then calling functions empirical_rxx() and marginal_rxx(). The first estimates the reliability in the present sample, and the second estimates the reliability assuming a given probability distribution (usually the Guassian). Both however produced the same value in this dataset.
} 

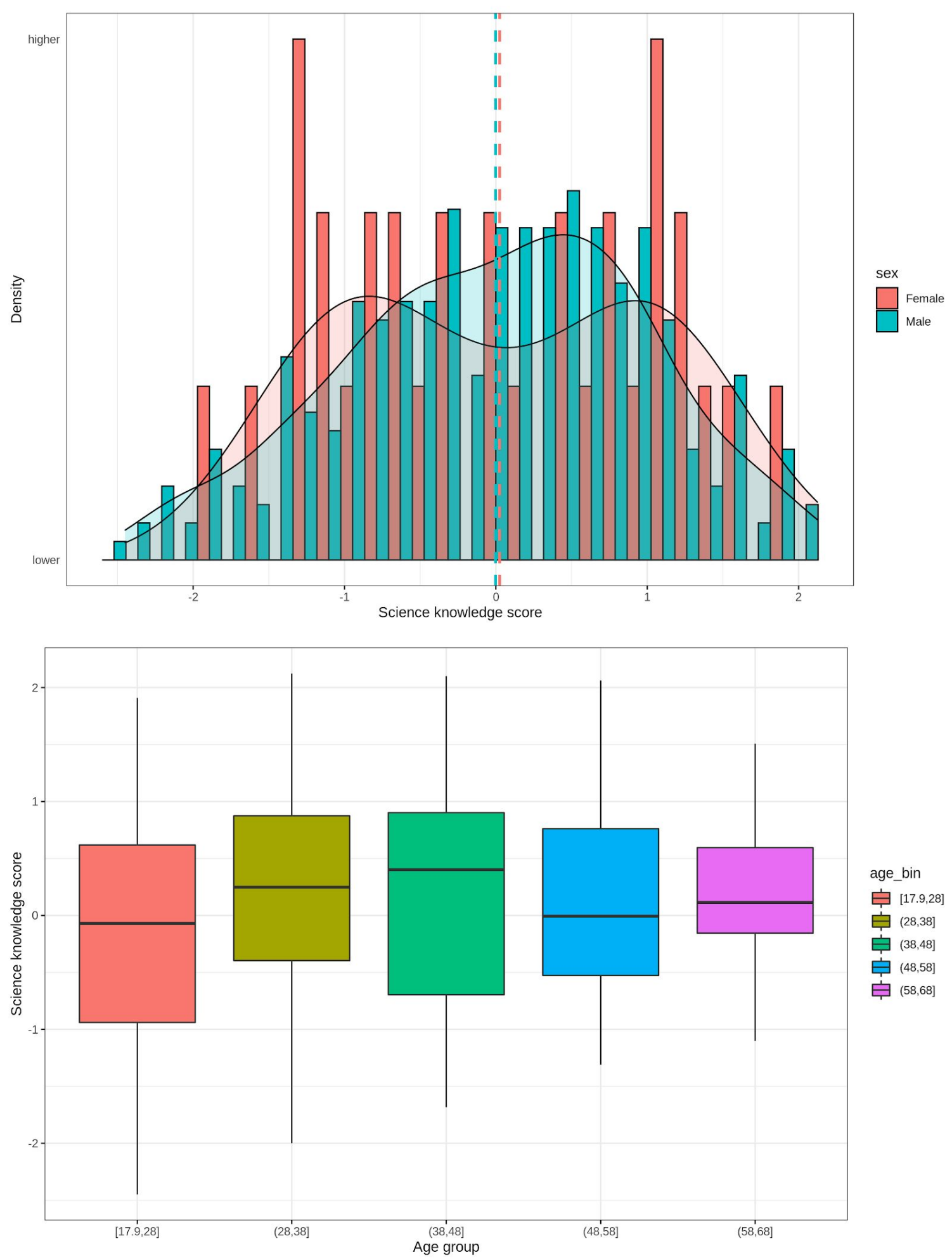

Figures Xa-b. Science knowledge score (IRT) by sex, and age bins. Vertical lines in the first plot show the means.

Females obtained slightly higher scores, $d=0.03$ but it was not beyond chance levels. Older persons obtained higher scores, $r=.16$ [.05 to .26, $p=.004$ ], as did more educated persons, $r=.24$ [.13 to $.33, p<.001]$. In a joint regression with age, sex, and education (numerical) to predict the science knowledge score, only education had a 
small but detectable effect $(\beta=0.21, p=.007)$. This probably reflects the self-selected nature of the sample, which were recruited because they were following a Twitter account that mostly posts science related topics.

\section{Forecasts}

Table X provides the summary statistics for each numerical forecast.

\begin{tabular}{|c|c|c|c|c|c|c|c|}
\hline $\begin{array}{l}\text { Questio } \\
\text { n }\end{array}$ & Mean & Sd & Median & $\begin{array}{l}\text { Trimme } \\
\text { d mean } \\
10 \text { pct }\end{array}$ & Mad & Min & Max \\
\hline $\begin{array}{l}\text { What do } \\
\text { you } \\
\text { estimate } \\
\text { will be } \\
\text { the total } \\
\text { death toll } \\
\text { of } \\
\text { Coronavi } \\
\text { rus in } \\
\text { the USA } \\
\text { in the } \\
\text { next } 2 \\
\text { years? }\end{array}$ & $\begin{array}{l}2824938 \\
.81\end{array}$ & $\begin{array}{l}1415886 \\
0.22\end{array}$ & $\begin{array}{l}150000 . \\
00\end{array}$ & $\begin{array}{l}576411 . \\
58\end{array}$ & $\begin{array}{l}218126 . \\
04\end{array}$ & 1.00 & $\begin{array}{l}2000000 \\
00.00\end{array}$ \\
\hline $\begin{array}{l}\text { What do } \\
\text { you } \\
\text { estimate } \\
\text { will be } \\
\text { the total } \\
\text { death toll } \\
\text { of } \\
\text { Coronavi } \\
\text { rus in } \\
\text { Europe } \\
\text { in the } \\
\text { next } 2 \\
\text { years? }\end{array}$ & $\begin{array}{l}1617267 \\
.05\end{array}$ & $\begin{array}{l}5120847 \\
.63\end{array}$ & $\begin{array}{l}150000 . \\
00\end{array}$ & $\begin{array}{l}550428 . \\
42\end{array}$ & $\begin{array}{l}214977 . \\
00\end{array}$ & 1.00 & $\begin{array}{l}5500000 \\
0.00\end{array}$ \\
\hline $\begin{array}{l}\text { What do } \\
\text { you } \\
\text { estimate } \\
\text { will be } \\
\text { the total } \\
\text { death toll }\end{array}$ & $\begin{array}{l}430817 . \\
66\end{array}$ & $\begin{array}{l}2351641 \\
.27\end{array}$ & $\begin{array}{l}30000.0 \\
0\end{array}$ & $\begin{array}{l}120624 . \\
48\end{array}$ & $\begin{array}{l}43440.1 \\
8\end{array}$ & 1.00 & $\begin{array}{l}4000000 \\
0.00\end{array}$ \\
\hline
\end{tabular}




\begin{tabular}{|c|c|c|c|c|c|c|c|}
\hline $\begin{array}{l}\text { of } \\
\text { Coronavi } \\
\text { rus in } \\
\text { the } \\
\text { United } \\
\text { Kingdom } \\
\text { in the } \\
\text { next } 2 \\
\text { years? }\end{array}$ & & & & & & & \\
\hline $\begin{array}{l}\text { What do } \\
\text { you } \\
\text { estimate } \\
\text { will be } \\
\text { the total } \\
\text { death toll } \\
\text { of } \\
\text { Coronavi } \\
\text { rus in } \\
\text { Poland } \\
\text { in the } \\
\text { next } 2 \\
\text { years? }\end{array}$ & $\begin{array}{l}205064 . \\
94\end{array}$ & $\begin{array}{l}1926106 \\
.39\end{array}$ & $\begin{array}{l}10000.0 \\
0\end{array}$ & $\begin{array}{l}44061.0 \\
0\end{array}$ & $\begin{array}{l}14677.7 \\
4\end{array}$ & 0.00 & $\begin{array}{l}3500000 \\
0.00\end{array}$ \\
\hline $\begin{array}{l}\text { Which } \\
\text { percenta } \\
\text { ge of the } \\
\text { populatio } \\
\mathrm{n} \text { of } \\
\text { France } \\
\text { will have } \\
\text { been } \\
\text { infected } \\
\text { by } \\
\text { Coronavi } \\
\text { rus by } \\
\text { the end } \\
\text { of } 2020 ?\end{array}$ & 33.22 & 23.84 & 30.00 & 31.78 & 29.65 & 0.00 & 98.00 \\
\hline $\begin{array}{l}\text { Which } \\
\text { percenta } \\
\text { ge of the } \\
\text { populatio } \\
\text { n of Italy } \\
\text { will have } \\
\text { been }\end{array}$ & 38.29 & 25.49 & 35.00 & 37.43 & 37.06 & 0.00 & 98.00 \\
\hline
\end{tabular}




\begin{tabular}{|c|c|c|c|c|c|c|c|}
\hline $\begin{array}{l}\text { infected } \\
\text { by } \\
\text { Coronavi } \\
\text { rus by } \\
\text { the end } \\
\text { of } 2020 ?\end{array}$ & & & & & & & \\
\hline $\begin{array}{l}\text { Which } \\
\text { percenta } \\
\text { ge of the } \\
\text { populatio } \\
\mathrm{n} \text { of } \\
\text { Spain } \\
\text { will have } \\
\text { been } \\
\text { infected } \\
\text { by } \\
\text { Coronavi } \\
\text { rus by } \\
\text { the end } \\
\text { of } 2020 ?\end{array}$ & 34.74 & 24.47 & 30.00 & 33.42 & 29.65 & 0.00 & 98.00 \\
\hline $\begin{array}{l}\text { Which } \\
\text { percenta } \\
\text { ge of the } \\
\text { populatio } \\
\text { n of the } \\
\text { USA will } \\
\text { have } \\
\text { been } \\
\text { infected } \\
\text { by } \\
\text { Coronavi } \\
\text { rus by } \\
\text { the end } \\
\text { of } 2020 ?\end{array}$ & 33.17 & 23.49 & 30.00 & 31.72 & 29.65 & 0.00 & 98.00 \\
\hline $\begin{array}{l}\text { What is } \\
\text { the } \\
\text { probabilit } \\
\text { y that } \\
\text { the USA } \\
\text { will } \\
\text { declare } \\
\text { a state } \\
\text { of }\end{array}$ & 70.68 & 29.88 & 80.00 & 74.44 & 29.65 & 0.00 & 100.00 \\
\hline
\end{tabular}




\begin{tabular}{|c|c|c|c|c|c|c|c|}
\hline $\begin{array}{l}\text { emergen } \\
\text { cy as a } \\
\text { result of } \\
\text { Coronavi } \\
\text { rus in } \\
2020 ?\end{array}$ & & & & & & & \\
\hline $\begin{array}{l}\text { What is } \\
\text { the } \\
\text { probabilit } \\
y \text { that } \\
\text { German } \\
\text { y will } \\
\text { declare } \\
\text { a state } \\
\text { of } \\
\text { emergen } \\
\text { cy as a } \\
\text { result of } \\
\text { Coronavi } \\
\text { rus in } \\
2020 ?\end{array}$ & 69.92 & 29.04 & 80.00 & 73.34 & 29.65 & 0.00 & 100.00 \\
\hline $\begin{array}{l}\text { What is } \\
\text { the } \\
\text { probabilit } \\
\text { y that } \\
\text { the } \\
\text { United } \\
\text { Kingdom } \\
\text { will } \\
\text { declare } \\
\text { a state } \\
\text { of } \\
\text { emergen } \\
\text { cy as a } \\
\text { result of } \\
\text { Coronavi } \\
\text { rus in } \\
2020 ?\end{array}$ & 68.94 & 29.13 & 78.00 & 72.10 & 31.13 & 0.00 & 100.00 \\
\hline $\begin{array}{l}\text { What is } \\
\text { the } \\
\text { probabilit } \\
\text { y that } \\
\text { Sweden }\end{array}$ & 64.87 & 30.27 & 70.00 & 67.40 & 37.06 & 0.00 & 100.00 \\
\hline
\end{tabular}




\begin{tabular}{|c|c|c|c|c|c|c|c|}
\hline $\begin{array}{l}\text { will } \\
\text { declare } \\
\text { a state } \\
\text { of } \\
\text { emergen } \\
\text { cy as a } \\
\text { result of } \\
\text { Coronavi } \\
\text { rus in } \\
2020 ?\end{array}$ & & & & & & & \\
\hline $\begin{array}{l}\text { What is } \\
\text { the } \\
\text { probabilit } \\
\text { y you will } \\
\text { be } \\
\text { infected } \\
\text { with the } \\
\text { new } \\
\text { coronavi } \\
\text { rus in } \\
\text { the next } \\
\text { two } \\
\text { years? }\end{array}$ & 43.38 & 28.07 & 45.00 & 42.48 & 37.06 & 0.00 & 100.00 \\
\hline $\begin{array}{l}\text { What is } \\
\text { the } \\
\text { probabilit } \\
\text { y that } \\
\text { anyone } \\
\text { in your } \\
\text { immediat } \\
\text { e genetic } \\
\text { family } \\
\text { will be } \\
\text { infected } \\
\text { by the } \\
\text { coronavi } \\
\text { rus in } \\
\text { the next } \\
\text { two } \\
\text { years? }\end{array}$ & 64.45 & 31.04 & 75.00 & 67.24 & 32.62 & 0.00 & 100.00 \\
\hline
\end{tabular}

Table X. Forecasts summary statistics. 
Note that for the questions that involve estimating counts (1-4), a few persons produced either extremely low or extremely high values. We suggest the reader looks at the trimmed mean (based on the middle $80 \%$ of the data) and the median for these forecasts to avoid the effects of the extreme values.

Looking at the medians and trimmed means, we see rather disturbing estimates. For instance, for the question "What do you estimate will be the total death toll of Coronavirus in the USA in the next 2 years?", the trimmed mean is $576 \mathrm{k}$ and the median is $150 \mathrm{k}$ deaths. These are both massive numbers, which are similar for the Europe parallel question $(\sim 550 \mathrm{k}, 150 \mathrm{k})$. When asked to estimate the prevalence in France of infected persons ${ }^{7}$, the central tendency metrics are all close to $30 \%$ (30 to 33\%). The values are similar for the parallel questions for Italy, Spain, and the USA (30-38\%). With regards to government stability, the forecasts of major Western countries entering a state of emergency are dire: 65 to $80 \%$ across Sweden, United Kingdom, Germany, and USA. Finally, individuals estimated their own chance of being infected at approximately $43 \%$, while they estimate it for a person in their immediate (genetic) family to be about. $64-75 \%$. It is curious to note that individuals rated their own risk higher than any of the four countries inquired about. This suggests they regard themselves as being especially high risk, perhaps because they are based predominantly in large cities, or because they perceive themselves to be risk takers. Alternatively, they may have misunderstood the question, or were simply being epistemically inconsistent. In the supplementary materials, we provide figures for each forecast, similar to the one shown in Figure $\mathrm{X}$.

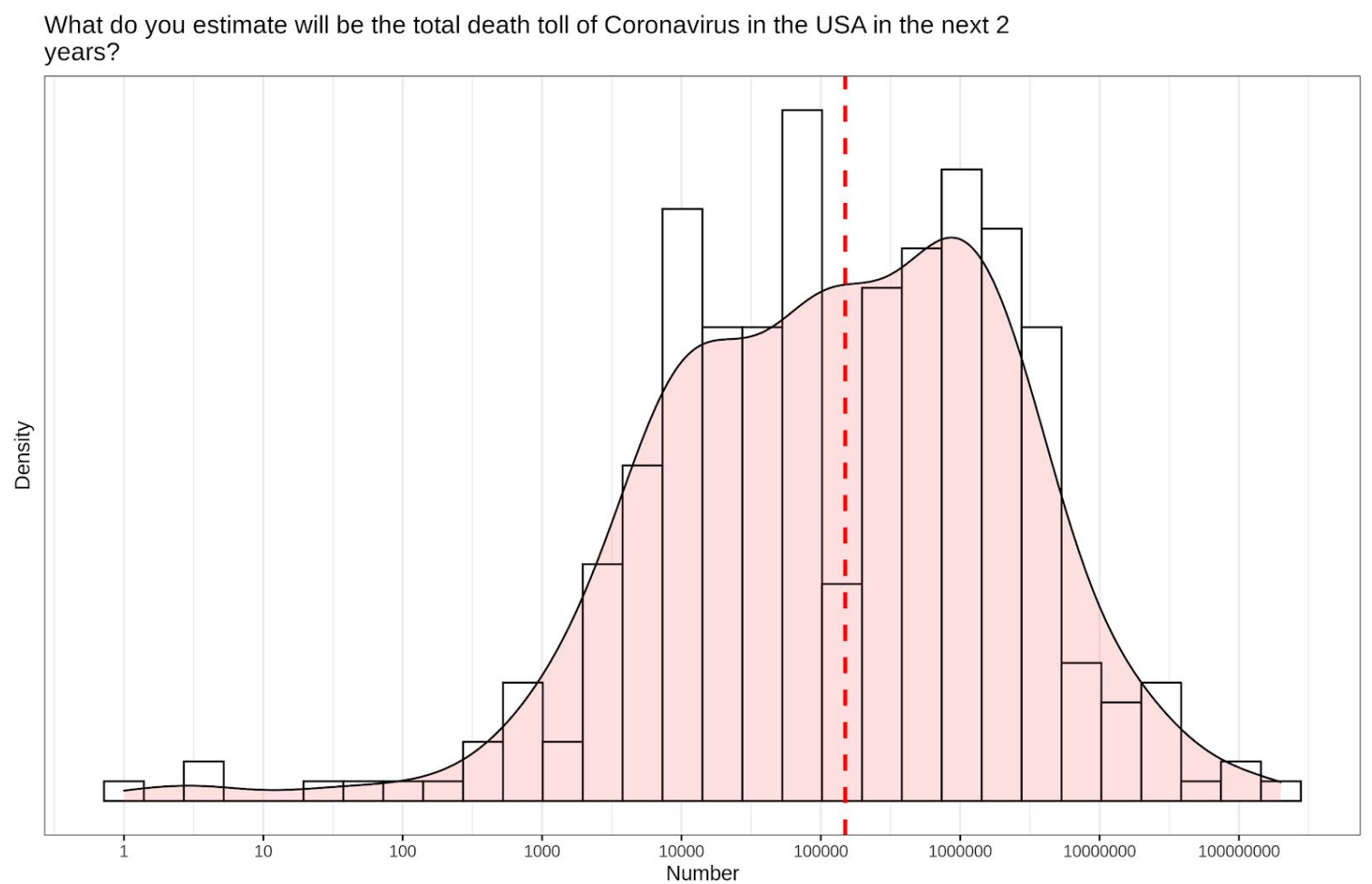

${ }^{7}$ This question explicitly told the subjects to include people who are now cured, or who died already. 
Figure X. Estimated total death toll from Coronavirus in the USA within 2 years. Based on 284 estimates. Vertical line shows the mean.

Four of the forecasts asked about dates and thus we did not calculate summary statistics for them. They asked "When do you think the rate of new infections will peak in [USA, Germany, Europe, UK]?. Figure X shows the distribution of forecasts of this peak.

Figure X. Distribution of forecasts of peak cases.

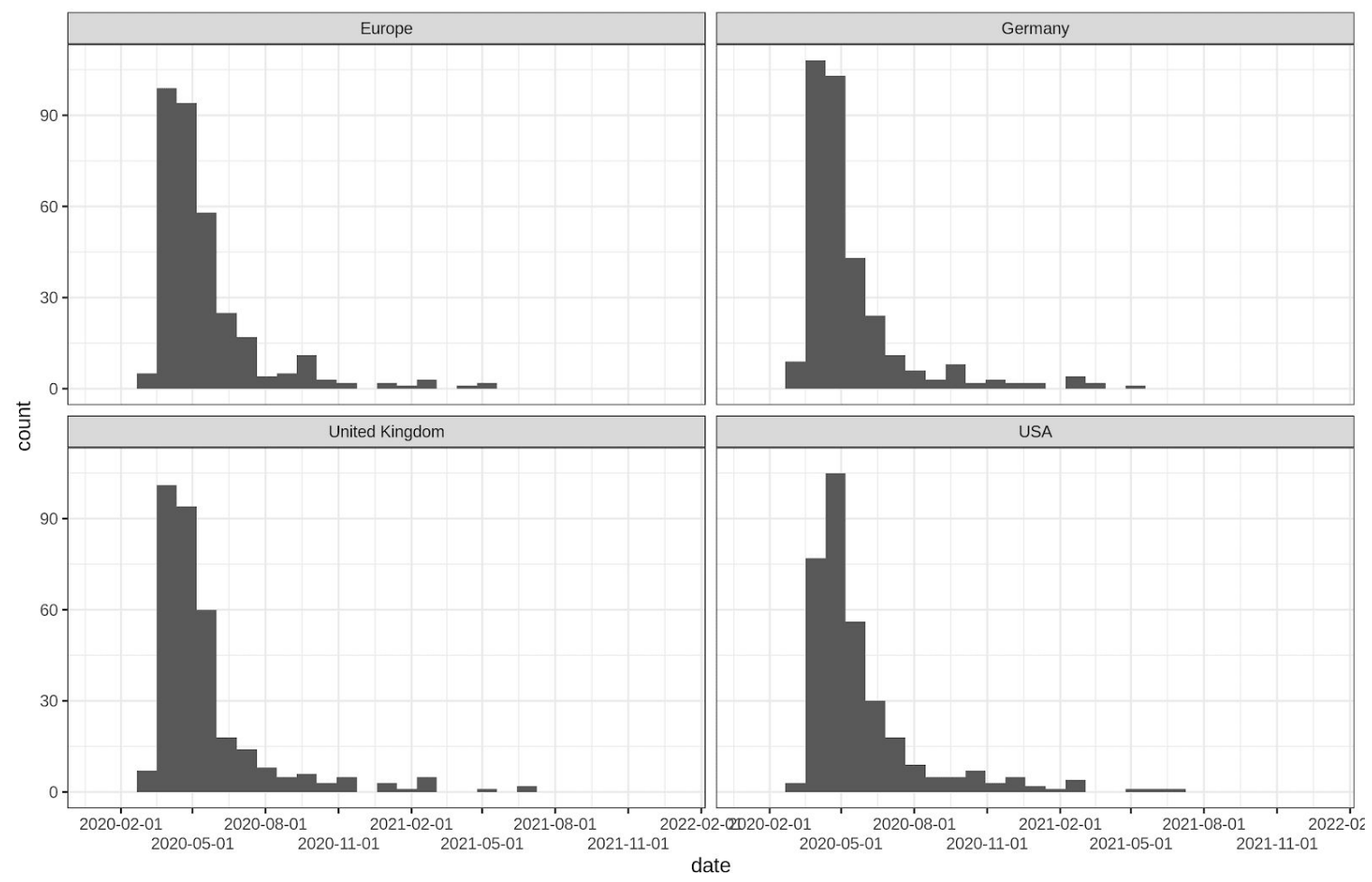

It can be seen that people have fairly similar forecasts for the 4 countries/regions. The median values were: 1st May, 22nd April, 30th April, and 28th April, respectively, for the USA, Germany, Europe, and the UK.

\section{Forecasts and individual characteristics}

Finally, we looked at the relationship between the individual variables in comparison with the severity of predictions given. Are persons with more expertise more optimistic, or more gloomy? First, we derived a general index of gloominess by factor analyzing the 14 forecasts that involved intensity (we left out the 4 forecasts regarding peak of new infections). To do this, we converted the data to rank-order values to avoid the extreme range and skew of values causing issues with the analysis. The expectation here was that all the variables would be positively correlated. Figure $X$ shows that this was the case. 


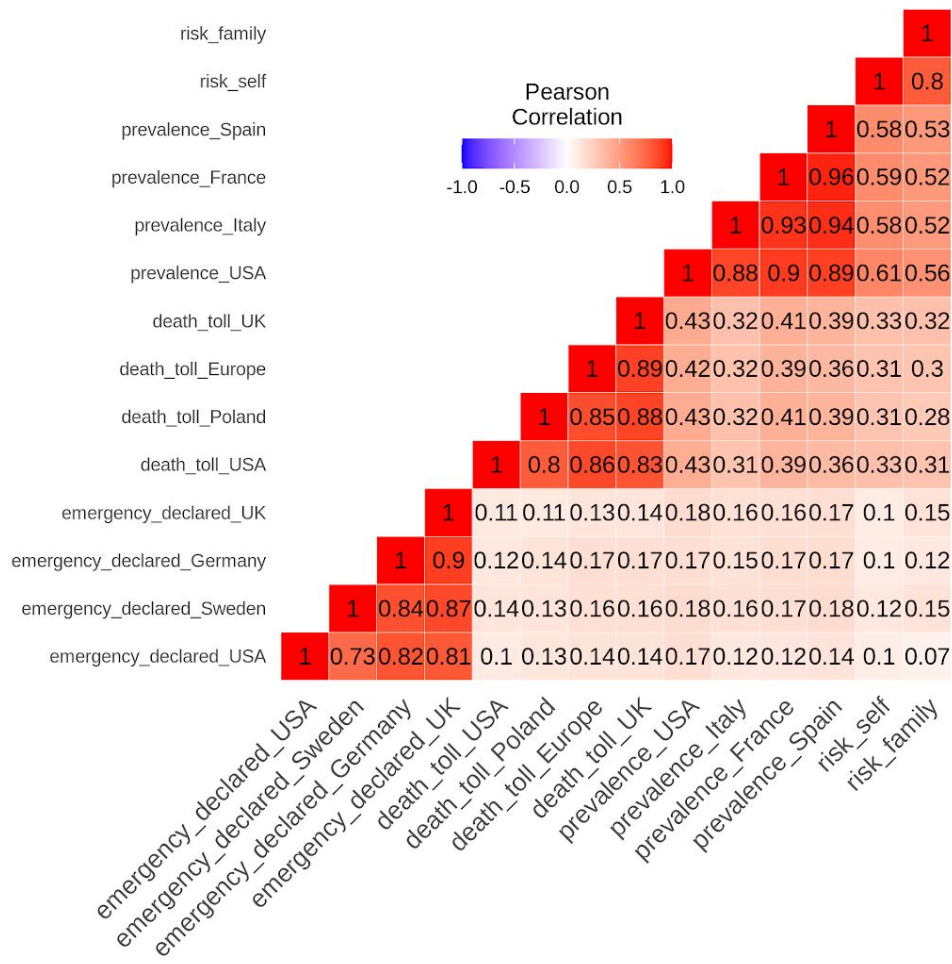

Figure X. Heatmap of correlations among forecasts.

We factor analyzed the forecasts to produce a single factor, with a mean loading of 61 and SD of .20 (variance for factor $=41 \%$ ). The scores from this analysis were roughly normal (skew $=-0.38$, kurtosis $=-1.45$ ). Note that Figure $X$ shows that there are clearly strong group factors in the data, as questions asked with the same scale show much stronger correlations among each other. However, such method factors were not of interest to us, so we proceeded with our general factor as an overall index. On this variable, higher values indicate greater levels of Coronavirus pessimism (colloquially, the 'doomer perspective') while lower scores indicate more Coronavirus optimism (the 'bloomer perspective'). We fit a series of increasingly complex regression models to predict this forecast general index. Table $\mathrm{X}$ shows the regression model results.

\begin{tabular}{|l|l|l|l|l|l|}
\hline $\begin{array}{l}\text { Predictor/M } \\
\text { odel }\end{array}$ & $\mathbf{1}$ & $\mathbf{2}$ & $\mathbf{3}$ & $\mathbf{4}$ & $\mathbf{5}$ \\
\hline Intercept & $0.00(0.055)$ & $0.06(0.177)$ & $0.09(0.179)$ & $0.07(0.182)$ & $\begin{array}{l}-0.02 \\
(0.200)\end{array}$ \\
\hline $\begin{array}{l}\text { Science } \\
\text { knowledge }\end{array}$ & $0.07(0.055)$ & $0.05(0.056)$ & $0.03(0.059)$ & $0.02(0.059)$ & $0.02(0.061)$ \\
\hline age & & $0.07(0.056)$ & $0.07(0.063)$ & $0.06(0.064)$ & $0.06(0.065)$ \\
\hline sex=Male & & -0.07 & -0.09 & -0.08 & -0.08 \\
\hline
\end{tabular}




\begin{tabular}{|c|c|c|c|c|c|}
\hline & & $(0.186)$ & $(0.189)$ & $(0.192)$ & $(0.194)$ \\
\hline education & & & $\begin{array}{l}-0.05 \\
(0.064)\end{array}$ & $\begin{array}{l}-0.04 \\
(0.065)\end{array}$ & $\begin{array}{l}-0.05 \\
(0.066)\end{array}$ \\
\hline book index & & & $0.13(0.059)$ & $0.10(0.061)$ & $0.11(0.062)$ \\
\hline $\begin{array}{l}\text { fox-hedgeho } \\
g\end{array}$ & & & $0.02(0.056)$ & $0.02(0.057)$ & $0.02(0.057)$ \\
\hline rationalist & & & $0.06(0.055)$ & $0.03(0.058)$ & $0.03(0.059)$ \\
\hline HBD & & & $0.06(0.056)$ & $0.09(0.062)$ & $0.09(0.063)$ \\
\hline $\begin{array}{l}\text { pol factor } \\
\text { libertarianis } \\
\text { h }\end{array}$ & & & & $0.00(0.064)$ & $\begin{array}{l}-0.01 \\
(0.064)\end{array}$ \\
\hline $\begin{array}{l}\text { pol factor } \\
\text { altrightish }\end{array}$ & & & & $0.09(0.061)$ & $0.09(0.062)$ \\
\hline $\begin{array}{l}\text { pol factor } \\
\text { left-liberalis } \\
\text { h }\end{array}$ & & & & $0.01(0.063)$ & $0.01(0.063)$ \\
\hline income tax & & & & $0.06(0.060)$ & $0.06(0.061)$ \\
\hline from USA & & & & & $0.13(0.125)$ \\
\hline from UK & & & & & $0.17(0.177)$ \\
\hline from France & & & & & $0.23(0.314)$ \\
\hline R2 adj. & 0.001 & 0 & 0.008 & 0.005 & 0.001 \\
\hline $\mathrm{N}$ & 333 & 333 & 333 & 333 & 332 \\
\hline
\end{tabular}

Table X. Regression model results to predict the general index of forecasts (overall severity of CV effects). ${ }^{*}=p<.01,{ }^{* *}=p<.005,{ }^{* * *}=p<.001$. Standardized betas shown.

Surprisingly, nothing we tried predicted the outcome well. Even the final model with 12 predictors had an adjusted R2 of $0.001 \%$ ! To test whether this resulted from our aggregation of forecasts into a single variable, we repeated the regression for each of the 14 component variables. However, we found materially the same result for these. Only a few variables were beyond chance. People from the US were much more inclined to think countries declare a state of emergency ( $\beta$ 's $=.49, .50, .52, .48$, for US, Germany, UK, and Sweden, respectively; each had a $p$ value of $<.001$ ). Full regression output can be found in the supplementary materials. 
Interestingly, our models showed a minor and positive (albeit unreliable) relationship between the severity of predictions and the degree of science knowledge exhibited by survey respondents. To see how this affected the estimates, we calculated the median result and trimmed the mean forecast for a three-way equal-sized split of CV-expertise, shown in Table $X$.

\begin{tabular}{|c|c|c|c|c|c|c|}
\hline Question & Median low & $\begin{array}{l}\text { Median } \\
\text { medium }\end{array}$ & Median high & Tmean low & $\begin{array}{l}\text { Tmean } \\
\text { medium }\end{array}$ & Tmean high \\
\hline $\begin{array}{l}\text { What do you } \\
\text { estimate will } \\
\text { be the total } \\
\text { death toll of } \\
\text { Coronavirus in } \\
\text { the USA in the } \\
\text { next } 2 \text { years? }\end{array}$ & 100000 & 150000 & 270000 & 485046 & 581596 & 695678 \\
\hline $\begin{array}{l}\text { What do you } \\
\text { estimate will } \\
\text { be the total } \\
\text { death toll of } \\
\text { Coronavirus in } \\
\text { Europe in the } \\
\text { next } 2 \text { years? }\end{array}$ & 80000 & 200000 & 250000 & 278087 & 671421 & 779102 \\
\hline $\begin{array}{l}\text { What do you } \\
\text { estimate will } \\
\text { be the total } \\
\text { death toll of } \\
\text { Coronavirus in } \\
\text { the United } \\
\text { Kingdom in } \\
\text { the next } 2 \\
\text { years? }\end{array}$ & 25000 & 30000 & 50000 & 75318 & 126650 & 164400 \\
\hline $\begin{array}{l}\text { What do you } \\
\text { estimate will } \\
\text { be the total } \\
\text { death toll of } \\
\text { Coronavirus in } \\
\text { Poland in the } \\
\text { next } 2 \text { years? }\end{array}$ & 7000 & 10000 & 20000 & 19386 & 53408 & 64587 \\
\hline $\begin{array}{l}\text { When do you } \\
\text { think the rate } \\
\text { of new } \\
\text { infections will } \\
\text { peak in the } \\
\text { USA? }\end{array}$ & $2020-05-01$ & $2020-05-01$ & $2020-05-01$ & 2020-05-09 & $2020-05-12$ & $2020-05-10$ \\
\hline $\begin{array}{l}\text { When do you } \\
\text { think the rate } \\
\text { of new } \\
\text { infections will } \\
\text { peak in } \\
\text { Germany? }\end{array}$ & $2020-04-16$ & $2020-04-30$ & $2020-04-20$ & $2020-04-27$ & $2020-04-29$ & 2020-04-27 \\
\hline
\end{tabular}




\begin{tabular}{|c|c|c|c|c|c|c|}
\hline $\begin{array}{l}\text { When do you } \\
\text { think the rate } \\
\text { of new } \\
\text { infections will } \\
\text { peak in } \\
\text { Europe? }\end{array}$ & $2020-04-26$ & $2020-05-01$ & $2020-04-30$ & 2020-05-01 & $2020-05-04$ & $2020-05-05$ \\
\hline $\begin{array}{l}\text { When do you } \\
\text { think the rate } \\
\text { of new } \\
\text { infections will } \\
\text { peak in the } \\
\text { United } \\
\text { Kingdom? }\end{array}$ & $2020-04-23$ & $2020-04-30$ & $2020-04-25$ & 2020-04-29 & $2020-05-02$ & $2020-05-06$ \\
\hline $\begin{array}{l}\text { Which } \\
\text { percentage of } \\
\text { the population } \\
\text { of France will } \\
\text { have been } \\
\text { infected by } \\
\text { Coronavirus } \\
\text { by the end of } \\
2020 ?\end{array}$ & 0.30 & 0.30 & 0.30 & 0.33 & 0.29 & 0.33 \\
\hline $\begin{array}{l}\text { Which } \\
\text { percentage of } \\
\text { the population } \\
\text { of Italy will } \\
\text { have been } \\
\text { infected by } \\
\text { Coronavirus } \\
\text { by the end of } \\
2020 ?\end{array}$ & 0.35 & 0.35 & 0.40 & 0.38 & 0.35 & 0.39 \\
\hline $\begin{array}{l}\text { Which } \\
\text { percentage of } \\
\text { the population } \\
\text { of Spain will } \\
\text { have been } \\
\text { infected by } \\
\text { Coronavirus } \\
\text { by the end of } \\
2020 ?\end{array}$ & 0.30 & 0.30 & 0.35 & 0.35 & 0.31 & 0.35 \\
\hline $\begin{array}{l}\text { Which } \\
\text { percentage of } \\
\text { the population } \\
\text { of the USA } \\
\text { will have been } \\
\text { infected by } \\
\text { Coronavirus } \\
\text { by the end of } \\
2020 ?\end{array}$ & 0.30 & 0.30 & 0.30 & 0.33 & 0.30 & 0.33 \\
\hline
\end{tabular}




\begin{tabular}{|c|c|c|c|c|c|c|}
\hline $\begin{array}{l}\text { What is the } \\
\text { probability } \\
\text { that the USA } \\
\text { will declare a } \\
\text { state of } \\
\text { emergency as } \\
\text { a result of } \\
\text { Coronavirus in } \\
2020 ?\end{array}$ & 0.80 & 0.80 & 0.80 & 0.75 & 0.74 & 0.75 \\
\hline $\begin{array}{l}\text { What is the } \\
\text { probability } \\
\text { that Germany } \\
\text { will declare a } \\
\text { state of } \\
\text { emergency as } \\
\text { a result of } \\
\text { Coronavirus in } \\
2020 ?\end{array}$ & 0.80 & 0.80 & 0.80 & \begin{tabular}{|l|l} 
\\
\end{tabular} & 0.73 & 0.73 \\
\hline $\begin{array}{l}\text { What is the } \\
\text { probability } \\
\text { that the } \\
\text { United } \\
\text { Kingdom will } \\
\text { declare a } \\
\text { state of } \\
\text { emergency as } \\
\text { a result of } \\
\text { Coronavirus in } \\
2020 ?\end{array}$ & 0.75 & 0.75 & 0.80 & 0.71 & 0.71 & 0.74 \\
\hline $\begin{array}{l}\text { What is the } \\
\text { probability } \\
\text { that Sweden } \\
\text { will declare a } \\
\text { state of } \\
\text { emergency as } \\
\text { a result of } \\
\text { Coronavirus in } \\
2020 ?\end{array}$ & 0.70 & 0.70 & 0.75 & 0.66 & 0.68 & 0.68 \\
\hline $\begin{array}{l}\text { What is the } \\
\text { probability you } \\
\text { will be } \\
\text { infected with } \\
\text { the new } \\
\text { coronavirus in } \\
\text { the next two } \\
\text { years? }\end{array}$ & 0.40 & 0.45 & 0.50 & 0.41 & 0.41 & 0.46 \\
\hline $\begin{array}{l}\text { What is the } \\
\text { probability } \\
\text { that anyone in } \\
\text { your } \\
\text { immediate } \\
\text { genetic family } \\
\text { will be } \\
\text { infected by } \\
\text { the }\end{array}$ & 0.70 & 0.70 & 0.80 & 0.63 & 0.67 & 0.72 \\
\hline
\end{tabular}




\begin{tabular}{|l|l|l|l|l|l|l|}
\hline $\begin{array}{l}\text { coronavirus in } \\
\text { the next two } \\
\text { years? }\end{array}$ & & & & & & \\
\hline
\end{tabular}

Table X. Median and trimmed mean ( $80 \%$ data coverage) predictions by science knowledge level (three-way even split).

Table $\mathrm{X}$ shows that higher science knowledge predicts more gloomy predictions across most comparisons. The effect sizes are quite massive in natural units. For instance, the upper third most knowledgeable persons had a median estimate of US deaths to CV of $270 \mathrm{k}$, compared with $100 \mathrm{k}$ among the lower third. For Europe, the same values were $250 \mathrm{k}$ and $80 \mathrm{k}$. Overall, the more knowledgeable forecasters were somewhat more gloomy in some forecasts (death tolls), but not others.

\section{Discussion}

In the present study, we gathered opinions from a self-selected sample pool of generally high-information forecasters, and explored the relationships between the basic characteristics of these forecasters and the predictions they made. We generally found that forecast gloominess was unrelated to participants characteristics, which is surprising. There was a weak trend for the more knowledgeable subjects to make forecasts of higher death tolls, but even these patterns are maybe just noise. It is currently not possible to score the forecasts for accuracy, and hence we cannot compute predictors of accuracy. This will have to wait for a follow-up paper.

Our science knowledge tests produced a nearly perfect normal distribution of scores, with no floor or ceiling issues. Unfortunately, the results show that the test reliabilities were unsatisfactorily low, at .70 for the sumscores and .74 for the IRT scores. Looking at the item statistics, we found that 3 out of 30 items did not meet our arbitrary IRT-threshold of having a loading of at least .20. These items tested fringe knowledge of news media reporting on the new coronavirus. A possibility is that people who performed well on this test did not browse the news as obsessively as the people scoring points on these questions. It may be smart to try to exclude questions about news articles that are too obscure in future projects.

\section{Metadata}

Supplementary materials including raw data available at https://osf.io/9ecwv/.

The authors involved declare no conflicts of interest. No funding was received for this study.

\section{References}

(implemented manually for now, Zotero is proving problematic on my mac distro)

1. Coronavirus disease (COVID-19) outbreak. (2020). World Health Organization. https://www.who.int/emergencies/diseases/novel-coronavirus-2019 
2. Heymann, D. L., \& Shindo, N. (2020). COVID-19: what is next for public health? The Lancet, 6736(20), 19-21. https://doi.org/10.1016/S0140-6736(20)30374-3

3. Lufkin, B. (2020). Coronavirus: The psychology of panic buying. Retrieved from https://www.bbc.com/worklife/article/20200304-coronavirus-covid-19-update-whypeople-are-stockpiling

4. Kahneman, D., \& Tversky, A. (1973). On the psychology of prediction. Psychological Review, 80(4), 237-251. https://doi.org/10.1037/h0034747

5. Mauksch, S., Gracht, H. A. Von Der, \& Gordon, T. J. (2020). Technological Forecasting \& Social Change Who is an expert for foresight ? A review of identi fi cation methods, 154(February 2019).

https://doi.org/10.1016/j.techfore.2020.119982

6. Chen, Nanshan, et al. 'Epidemiological and Clinical Characteristics of 99 Cases of 2019 Novel Coronavirus Pneumonia in Wuhan, China: A Descriptive Study'. The Lancet, vol. 395, no. 10223, Feb. 2020, pp. 507-13. DOl.org (Crossref), doi:10.1016/S0140-6736(20)30211-7.

7. Dimmock, N. J., et al. Introduction to Modern Virology. Seventh edition, John Wiley \& Sons, Inc, 2016.

8. Louten, Jennifer, and Niki Reynolds. Essential Human Virology. Elsevier, Academic Press, 2016.

9. Miller, M. David, et al. Measurement and Assessment in Teaching. 10th ed, Merrill/Pearson, 2009. 